\title{
Status Analysis of Research on Russian Higher Education Management System
}

\author{
Lirong Song \\ Heihe University \\ Heihe, Heilongjiang, China, 164300
}

\begin{abstract}
In view of the historical origin of higher education between China and Russia, this paper will introduce and analyze the research status of higher education management system of both China and Russia, so as to reveal the development condition and trend of comparative research on higher education between China and Russia and provide some understandings and theoretical basis for people interested in the comparative research on higher education between China and Russia, as well as reference for the further research in the future.
\end{abstract}

Keywords-Russia; higher education; management system; research status; analysis

\section{INTRODUCTION}

With the recovery and development of the Russian economy, this problem has been attached greater and greater importance. The economic globalization promotes the internationalization and globalization of education, which is in urgent need to study and profit from the achievements of Russian higher education management system reform. Deeply discussing the problems of higher education management system and the factors restricting the education has been the trend of the times. This topic is trying to provide some research and discussion in this aspect, and expects to receive additional consideration from the higher education theory field.

From the research status of this field, the Russian higher education field is in the positive discussion and study of the higher education management system. However, as a result of unstable Russia's policy and management, there is a certain fuzziness and limitations. From the research status of Russian higher education management system by China, there is no systematic special works in research on Russian higher education management system reform, and there is few research achievements of Russian higher education management system and less study of the Russian higher education management system; the works mainly focuses on the introduction and description of overall situation of Russian higher education reform and the Russian higher

Fund projects: Key project of the 12th five-year plan of Heilongjiang education science - Research on Russian Higher Education Governance Capability Modernization and the Reference Significance (GJB1214024); financing project of humanities and social science research by Education Department of Heilongjiang Province - Research on the Russian Higher Education Legal Changes Impact on the Education in the Transitional Period (12522187). education administrative regulations and documents and a factual description of the Russian survey, and it is lacking in special in-depth research and analysis.

The domestic studies on Russian higher education mainly include: (1) macro dissertation. Russian Higher Education Reform - Education Shock from the End of the 20th Century (Zhang Nanxing, The Russian Research, 2002, 4.) and the Status and Reform Trend of Russian Higher Education (Cheng Enqing, Zhang Quanfen, Jin Jiling. Journal of Hebei University (Philosophy and social science), 2003, 2.) (2) Higher education system reform. Comment on Russian Higher Education System Reform (Chen Xianji. Comparative Education Research, 1998, 3.). (3) The translation of policy. Deng Luping. Russian Federation National Education Policy (Draft), etc. There are just a few articles focusing on "Russian higher education management system": "Introduction of the Russian Higher Education Universities Management System (Luan Jinghe. Russian Research, 1999, 2), Expanding the University's Decision Making Power: Commentary on the Russian Higher Education Management System Reform (Zhao Mengcheng. Higher Education Research of Mechanical Industry, 2001, 4.), Russian University Internal Management System Reform and the Enlightenment (Song Lirong. Siberian Research, 2008 , 4.). This paper begins with the research on legal documents of Russia, such as Higher Education and Postuniversity Education Law adopted by Russian Federation Duma in 1996, Russian Federation National Education Policy (Draft) adopted by Russian Federation in 1999.

This paper analyzes the status of Russian higher education management system from the aspects of Russian higher education administration system, the university internal management system reform and the enlightenment, and provides some data for the people interested in Russian education. It can also be as the feasibility of reference which is different from that of developed countries for current China's university curriculum reform.

\section{STATUS OF RUSSIAN UNIVERSITIES' INTERNAL MANAGEMENT SYSTEM}

\section{A. Internal Organization and Management of the Universities}

Internal management system of the universities varies due to the different types of the universities. The national 
and local universities implement the three levels of management including school, department and teaching and research section. Current Higher Education and Postuniversity Vocational Education Law of the Russian Federation stipulates that the management of Russia's universities is implemented in the principle of one man management with a collective leadership. Specific management institutions include:

First is the school board, also called the general meeting. It has the supreme right to speak in school academic affairs, teaching, social service, cultural exchanges and scientific activities and is the highest authority in the universities. The school board members are elected by the faculty and students, including the representatives from all disciplines, in which the percentage of undergraduate and graduate representatives shall not be less than $25 \%$. A term of the school board is five years; it is mainly responsible for the election of the president, review and approval of the articles of association of universities and its internal regulations, review of the issues of the school economy and development. The president and the articles of association should be approved by the Ministry of Education of Russia.

Second is the academic committee. The academic committee consists of the president and vice-president and other members elected by the all staff meeting of the university through secret ballot; the academic committee is managed by the university.

Third is the president. Management authority of the Russian universities has the similar settings, basically including the university leader, administration and logistics service. The management authority setup of a Russian university is shown below: [1]

1) University leaders:

The president - responsible for the overall work;

Standing (first) vice president - to assist the president;

Vice president of teaching - responsible for the teaching work;

Vice president of scientific research - responsible for the scientific research;

Vice president of foreign affairs - responsible for the foreign and international exchange and the students' management;

Vice president of general affairs - responsible for logistics support, planning \& construction and paid services.

2) Administrative management: the president's office, academic affairs office, scientific research division, personnel division, foreign affairs division (consists of foreign student affairs office), students service office, the postgraduate office.

3) Logistics services: financial planning department, accounting department, equipment, general services office, life service office and security office.

\section{B. University President}

A Russian university president should generally have the professor qualification, and the president is jointly elected by the school board, professors, lecturers, students and management personnel, who will also participate in school affairs. The president should have not only the quality of scholars and scientists, but also the ability of managers and financial experts. As the complicated functions of the university, the president qualifications have also become more complicated.

Two-level management is implemented in the large comprehensive university of Russia: the president, dean. Formerly, the president of a Russian university is appointed by the central government, and the staff belongs to the state personnel; the universities have no right to decide whether to employ the staff; after the reform, the universities won a larger staffing. University president is elected in democratic way. The universities are mainly led by school board and directly managed by the president, so as to divide the management of universities into strategic and tactic type. As the head of the university, the president has the nature of the legal representative, responsible for the organization of the school education teaching and foreign exchange. As chairman of the school board, the president has the right to appoint college or department leaders. But with the expansion of universities' decision making power, the President's power also increases accordingly. If there is no effective restriction and supervision, the president's power can be abused to lead to the development of university internal management absolutism..

\section{CHARACTERISTICS OF INTERNAL MANAGEMENT OF UNIVERSITIES}

Internal management system of Russia's universities is diverse, which is resulted from the promotion of diverse school-running modes since the independence of Russia. Regardless of the nature of the school, its internal management system reflects the principle of democratization combining the "state - society - the president - teachers students.

\section{A. "University Management by Professors"}

Departments of Russian universities are administrative organizations, and head of the department is elected by secret ballot, with a term of four years; the head of department is also the chairman of the academic committee. Teaching and research section is an academic organization, bearing both the teaching task and the discipline construction task. The head of the teaching and research section is elected, and he/she is generally the discipline leader; the head should attend the academic committee, and be responsible for the implementation of the teaching plan together with the deputy director of the teaching and research section, regularly organizing the meeting discussion of the section, as well as the graduate professional exams for both graduates and undergraduates. [2] The academic committee members participate in the major strategic analysis and decision- 
making of the school, to make the school discipline construction truly put into effect and focus on learning.

School administration is an implementing agency, and the supreme power organization of the school is academic committee; academic committee at all levels plays an important role in the school teaching, scientific research, personnel work. Universities advocate teacher undertaking the teaching, scientific research and management, and attach great importance to the position and role of the teachers in academic administration; therefore, "University Management by Professors" is generally implemented.

\section{B. Continuous Expansion of the Decision-making Power of the Universities}

Specific goal of Russia to expand the reform of universities' decision making power is complex, mainly including the following aspects: (1) changing the method that the higher education funds rely on the central government funding, trying to get the diversification of sources of funds and providing necessary power for the universities in terms of raising funds. (2) changing the practice that the competent department of the central government strictly controls the curriculum and teaching in universities, to encourage the innovation of teaching.(3) abolishing the practice of central government planning the universities admission, and expanding the power of the universities and employer in enrolment.(4) reforming the practice of separating the universities from the academy of sciences and industrial research center to make the universities equally compete with the academy of sciences and industrial research center on funds; strengthening the scientific research ability of the universities. [2] To some extent, the universities expand the power in the process of seeking survival rather than that the federal government promotes the reform process, which means that they will continue to be forward in the groping and also suggests that the reform to expand the decisionmaking power of universities still has a long way to go.

Expanding the decision-making power of the universities will require the reform of university internal management system; however, Russian universities haven't set up internal management system with balanced and reasonable power configuration, which will affect the reform results.

\section{Non-ideologization}

The Education Law of Russian Federation clearly stipulates that: "no party, social and political activity and groups and religious activity and organization shall be established in national and local education institutions and the education administration authorities, and no activity is allowed in these organizations." [3] As a result, there are no representatives of any political organizations and religious groups to participate in the management of Russian national and local universities. Non-national universities are not included. It has fundamental difference with the internal management system of former Soviet Union universities, because school board and academic committee of the former Soviet Union universities must contain the representatives of party committee of the communist party and the communist youth league.

\section{REFORM TREND OF HIGHER EDUCATION ADMINISTRATION SYSTEM}

According to the Education Law of Russian Federation, the Russian higher education implements the three-level management of federal government, the federation and local self-government institution, and each level has its explicit authority. And hierarchical management is carried out for different types of schools. Management departments of universities are divided into four parts: (1) Russian Federation; (2) Educational and Scientific Department (Education Department, etc.); (3) other ministries of Russian Federation; (4) all federal subjects or municipal governments. The federal level national universities are mainly governed by Educational Science Department of Russian Federation. With the further deepening of market competition mechanism, the reform of Russian higher education administrative system shows the following characteristics and trends.

\section{A. Market Trend}

Educational marketization is neither absolute privatization nor absolute socialization. It is the introduction of market mechanism, to maximize the efficiency. Russian education reform was conducted under the push of social transformation; from single administrative subordination relationship with the state, the education was pushed to the market. Local interests and school interests become a focal point of the education development. The concept of "market" was introduced into the higher education reform, to make the operation of universities to adapt to the social changes in market-oriented way. According to the flexibility of the market, the national education institutions also develop and utilize the existing resources and perfect the management system, to maintain the competitive position.

\section{B. Diversification Trend}

Russia is a multi-ethnic country with more than one hundred ethnic groups. Objectively, the country must implement unified education policy to maintain a unified education space. At the same time, the pluralistic economy and diversified social development, change of economic growth mode and adjustment of industrial structure will inevitably put forward diversified demand of higher education. Higher education has changed to multiple systems from the single system, Thus, only regular higher education system can't satisfy the wide social demand for higher education. Traditional higher education administrative system and the concept have changed significantly. Therefore, this period of higher education reform takes the "diversity" strategy, covering the education management right, educational subject and way, management structure, funds investment and talent training as "diversity" instead of the original "unitization". 


\section{Internationalization Trend}

In order to win human resources superiority in the information age, Russian authority paid more attention to prior position of the education development and actively responded to the construction of European higher education integration, and signed Bologna Declaration at Berlin in September 2003, which opened a new chapter of the internationalization of higher education management. The idea of internationalization of Russian higher education management mainly reflects in: adapting to the practical need of the talent by the market economy and the development trend of the international higher education; strengthening the international exchanges and cooperation; drawing lessons from the advanced experience of foreign universities; striving to cultivate "international" talent.

\section{FURTHER THINKING}

For Russia in the transitional period, whether the politics and economy, or the cultural education, something old have not been completely eliminated and new things have not been completely established. Management system reform is a complex process. It is difficult to reform a 70-year higher education management system; what's more, the social transformation and the current economic crisis also bring more uncertain factors. Therefore, for the process full of hardships, we are unable to comprehensively judge its existence yet. Taking the market economy as the starting point, the country as the main force and the diversification as the strategy, if the reform of Russian higher education management system can not only keep a Russian tradition but also adapt to the integration of the world, it will be the inspiration and reference for China's higher education management system reform and improvement. Such as, the combination of market guide and national macroeconomic regulation and control; strengthening the legal construction of education system; improving the mechanism of the higher education funding; transforming the management mechanism of higher education; changing the president selection system; setting up the concept of correct education quality and so on.

\section{REFERENCES}

[1] Cheng Enqing, Zhang Quanfen, Jin Jiling. Status and Reform Trend of Russian Higher Education [J]. Journal of Hebei University (Philosophy and social science), 2003 (2). 20.

[2] Zhao Mengcheng. Expanding the University's Decision Making Power: Commentary on the Russian Higher Education Management System Reform [J]. Higher Education Research of Mechanical Industry, 2001 (4), 83.

[3] Hu Guoming. Studies on the University Headmastership and University Development $[\mathrm{M}]$. Huazhong University of Science and Technology Press, 2004. 204. 